6. Kucherenko I. A. (2019) Teoretychni i metodychni zasady suchasnoho uroku ukrainskoi movy v osnovnii shkoli [Theoretical and methodological foundations of the modern lesson of the Ukrainian language in primary school]: dys. ... dokt. ped. nauk: 13.00.02. Khersonskyi derzhavnyi universytet. Kyiv. 561 s. [in Ukrainian]

7. Kucheruk O. A. (2001) Systema metodiv navchannia ukrainskoi movy v osnovnii shkoli: teoriia i praktyka [System of methods of teaching ukrainian in primary school: theory and practice]: Monohrafiia. Zhytomyr : Vyd-vo ZhDU imeni I. Franka, 2011. $420 \mathrm{~s}$. [in Ukrainian]

8. Omelchuk S. A. (2003) Formuvannia movlennievo-komunikatyvnykh umin uchniv osnovnoi shkoly na zavershalnomuetapi v yvchennia syntaksysu [Formation of speec handcommunication skills of elementary school students at the final stage of studying the syntax]: dys...kand. ped. nauk: 13.00.02. Instytut pedahohiky APN Ukrainy. Kyiv. 237 s. [in Ukrainian]

9. Pentyliuk M. I., Horoshkina, O. M., Nikitina A. V. (2006) Osnovy kohnityvnoi metodyky navchannia ukrainskoi movy [Fundamentals of cognitive teaching methodology of Ukrainian language]. Pedahohichni nauky. Vyp. 42. S. 57-62. [in Ukrainian]

10. Slovnyk-dovidnyk $z$ ukrainskoi linhvodydaktyky [Dictionary of Ukrainian Linguistics]. Kol. avtorivzared. M. I. Pentyliuk. Kyiv : Lenvit, 2015. 320 s. [inUkrainian]

\title{
Ohar Yu. V. System of personality oriented exercises and tasks of learning Ukrainian language in general secondary
} education

The article covers the system of personally oriented exercises and tasks in the process of teaching Ukrainian grammar in general secondary education institutions. On the basis of the analysis of the works of Ukrainian lingvodidakts the signs, approaches and criteria for the classification of exercises were determined and it was concluded that the formation of grammatically normative speech of students in the process of learning the grammar of the Ukrainian language would be effective if the system of personally oriented exercises and tasks were introduced into the educational process.

In grammar learning, students should not only recognize and classify language phenomena for morphological or syntactic parsing, but also be able to use language units of all levels in oral and written speech, pay attention to difficulties (morphological, syntactic errors), norms of language units, speech culture. Therefore, the development of personally oriented exercises and tasks in the process of teaching Ukrainian grammar in general secondary education institutions will focus as much as possible on the personal space of the high school student, peculiarities of mastering the material, clarifying the content of the subjective experience of the student, taking into account the material learned in the main school interests and abilities, development skills to set goals and systematically work on their realization.

It is determined that the obligatory component of the methodological system based on the subject-subject relations of the student and the teacher are complex exercises, among which the most expedient are motivational ones (stimulate the inner personal motives of the high school student to study grammatical units of speech, striving for literacy and general success), cognitive (analytical, analytical, synthetic, and constructive - analysis of linguistic material, creation, distribution, or replacement of individual text fragments), communicative (communication situations, communication teaching problem-search or research objectives) exercises.

Key words: grammar, task, complex exercise, morphological exercise, motivational exercise, syntactic exercise, person-centered approach.

\author{
УДК 378:796.011 \\ DOI https://doi.org/10.31392/2311-5491/2019-70.44
}

Олексієнко Я. І., Субота В. В., Головатенко О. М.

\section{ФОРМУВАННЯ ЗАГАЛЬНОЇ КОМПЕТЕНТНОСТІ У СТУДЕНТІВ ЗАКЛАДІВ ВИЩОЇ ОСВІТИ НА ЗАНЯТТЯХ 3 ФІЗИЧНОГО ВИХОВАННЯ}

У статті висвітлено актуальність компетентнісного підходу в системі вищої освіти. Обтрунтовано пріоритетність компетентнісного підходу в організації навчально-виховного процесу в закладах вищої освіти України. Проаналізовано загальні компетентності, якими має оволодіти студент-випускник. Розглянуто деякі проблеми й особливості формування загальних компетентностей у студентів на заняттях із фізичного виховання.

Компетентнісний підхід на заняттях із фізичного виховання допоможе реалізувати актуальні завдання сучасного навчання, сприяючи формуванню як загальних, так і спеціальних компетентностей студентів. Загальні компетентності - універсальні компетентності, що не залежать від предметної області, але важливі для успішної подальшої професійної та соичіальної діяльності здобувача в різних галузях, для його особистісного розвитку.

Студент-випускник вищої школи має володіти такими загальними компетентностями: здатність до аналізу та синтезу; уміння застосовувати знання на практиці; планування та розподіл часу; базові загальні знання сфери навчання; застосування базових знань професії на практиці; усне та письмове спілкування рідною мовою; знання другої мови; елементарні навички роботи з персональним комп ютером; дослідницькі уміння; здатність до самонавчання; навички роботи з інформачією (уміння знаходити й аналізувати інформацію з різних джерел); здатність до самокритики та критики; здатність адаптуватися до нових ситуацій; здатність генерувати нові ідеї.

До різних рівнів сформованості та прояву компетентностей у студентів можна віднести: 1) ступінь опанування та реалізації компетентностей у конкретному виді діяльності; 2) суб'єктивний чинник (залежність набуття компетентностей та їх реалізаиї в певному виді діяльності від притаманних конкретній особистості природних даних); 3) причинно-наслідовий зв'язок між сформованістю структурних компонентів компетентності.

Ключові слова: компетентнісний підхід, компетенція, компетентність, загальна компетентність, фізичне виховання, студент, заклад вищої освіти, заняття. 
У багатьох розвинутих країнах світу в системі освіти нормативним підходом до результатів професійної підготовки є компетентнісний підхід (В. Байденко, О. Жук, О. Заблоцька, Дж. Зантвоорт, G. Halasz, A. Michel та ін.). Пріоритетність компетентнісного підходу в організації навчально-виховного процесу в Україні і формування компетентностей у студентів визначені в ухвалених урядом нових нормативних документах, як-от Державний стандарт базової і повної загальної середньої освіти, Національна стратегія розвитку освіти в Україні на період до 2021 р. Так, Національна стратегія розвитку освіти в Україні визначає кардинальні зміни, спрямовані на підвищення конкурентоспроможності та якості освіти в нових економічних і соціокультурних умовах, прискорення інтеграції України в міжнародний освітній простір [1;2].

Актуальність компетентнісного підходу висвітлено в матеріалах модернізації освіти і розглянуто як одне з важливих положень оновлення ії змісту. Це зумовлено тим, що професійна діяльність характеризується зростанням складності, динамікою і перевантаженням. Основним же завданням компетентнісного навчання є формування фахівця, здатного вирішувати професійні проблеми в нових ситуаціях [3, с. 177; 4].

Ідеї компетентнісного підходу є предметом наукового пошуку таких учених, як: А. Баранніков, В. Болотов, І. Зимня, В. Краєвський, В. Сєріков, А. Хуторський та ін. Аналіз сутності та характеристику складових частин зазначеного підходу відображено в дослідженнях вітчизняних науковців - О. Локшиної, О. Пометун, В. Свистун, А. Проценко, В. Ягупова; сучасні тенденції розвитку змісту освіти в закордонних країнах аналізувалися К. Корсаком, О. Овчарук, Я. Кодлюк; уміння вчитися як ключова компетентність розкрито О. Савченко.

Осмислення й узагальнення компетентності в освітньому просторі здійснили вітчизняні вчені: Н. Бібік, Л. Ващенко, А. Кузьмінський, В. Луговий, Г. Малик, Н. Побірченко, С. Трубачова, М. Чобітько й ін., а також закордонні - Е. Занкова, Г. Кашкорова, Дж. Равен, І. Стеценко, М. Уїммер, Ч. Ліяня.

Аналіз філософської, педагогічної, психологічної, соціологічної та валеологічної літератури дає підстави стверджувати, що означена проблема сьогодні надзвичайно актуальна, але повною мірою не вивчена. Необхідність подальшого розроблення даної проблеми зумовила вибір теми нашого дослідження: «Формування загальної компетентності у студентів закладів вищої освіти на заняттях з фізичного виховання».

Мета статті - дослідити зміст і особливості формування загальних компетентностей у студентів на заняттях із фізичного виховання.

Методи дослідження: 1) теоретичні - аналіз філософської, психолого-педагогічної, культурологічної літератури, дисертаційних досліджень; синтез, порівняння й узагальнення отриманих даних із метою визначення підходів до сутності понять «компетентнісний підхід» і «загальна компетентність»; 2) емпіричні педагогічне спостереження, бесіди, вивчення й узагальнення педагогічного досвіду.

Наукові дослідження Н. Кузьміної (1993р.), О. Петуніна (1996 р.), Ю. Шкребтія (1996 р.), М. Данилка (2000 р.), П. Сфіменка (2002 р.), О. Солтика (2003 р.), Л. Сущенко (2003, 2009 рр.), Т. Осадчої (2005 р.), Р. Карпюка (2005 р.), О. Печка (2015 р.) переконують, що головною метою навчання студентів у закладі вищої освіти (далі - ЗВО) є формування в них загальних і професійних компетентностей та готовності до професійного мислення і діяльності. Це особливо актуально сьогодні, оскільки, інтегруючись в європейський простір, освітня парадигма України має зосередитись на положенні про те, що основними результатами діяльності закладів вищої освіти мусить стати не система знань, умінь та навичок, а сформованість сукупності компетентностей спеціаліста в певній професійній сфері, причому сукупність компетентностей спеціаліста окрмої галузі визначається державними класифікаторами професій. Реєстр компетентностей може бути використаний як під час проєктування навчальних програм, що дасть змогу студентам усвідомлено й індивідуально вибирати навчальні програми, так і для побудови та реалізації програм і процедур сертифікації спеціаліста. Звідси виникає необхідність розглядати професійну підготовку студентів із позицій компетентнісного підходу, який можна вважати способом досягнення нової якості освіти [5].

Останнім часом компетентнісний підхід стає все більше поширеним і претендує на роль концептуальної освітньої політики, яка здійснюється як державами, так і впливовими міжнародними організаціями, підсилює практичну орієнтацію освіти, підкреслює значення досвіду, умінь і навичок, що спираються на наукові знання [6].

На сьогодні існує багато трактувань поняття «компетентнісний підхід», наприклад: «це підхід, що акцентує увагу на результаті освіти, причому як результат розглядається не сума засвоєної інформації, а здатність людини діяти в різних проблемних ситуаціях; це підхід, за якого результати визнаються значущими за межами системи освіти» [7].

Поняття «компетентнісний підхід» розуміється як спрямованість освітнього процесу на формування та розвиток ключових (основні) і предметних компетентностей особистості [8]. Результатом такого процесу буде формування загальної компетентності людини, що є сукупністю ключових компетентностей, інтегрованою характеристикою особистості. Така характеристика має сформуватися у процесі навчання і містити знання, уміння, ставлення, досвід діяльності та поведінкові моделі особистості.

Компетентнісний підхід в освіті грунтується на важливих поняттях «компетенція» та «компетентність», філософська інтерпретація яких, з одного боку, фіксує деяку невизначеність, а з іншого - ускладнює вживання цих термінів. На сьогодні немає єдиної класифікації компетентностей і компетенцій, як немає і єдиного погляду на те, скільки і яких компетентностей має бути сформовано у студентів. Так, у частині першій 
ст. 1 Закону України «Про вищу освіту» зазначено, що компетентність - динамічна комбінація знань, умінь і практичних навичок, способів мислення, професійних, світоглядних і громадянських якостей, моральноетичних цінностей, яка визначає здатність особи успішно здійснювати професійну та подальшу навчальну діяльність і є результатом навчання на певному рівні вищої освіти [9].

У Державному стандарті поняття вживаються в такому значенні [1]: компетентність - набута у процесі навчання інтегрована здатність учня, що складається із знань, умінь, досвіду, цінностей і ставлення, що можуть цілісно реалізовуватися на практиці; компетенція - суспільно визнаний рівень знань, умінь, навичок, ставлень у певній сфері діяльності людини.

У «Словнику іншомовних слів» [10, с. 402] визначено, що компетенція - це низка питань, у яких будьхто є обізнаним, а компетентність - це: наявність компетенції; наявність знань, що дозволяють судити про що-небудь.

Фізичне виховання, важлива складова частина освіти, спрямоване на формування здоров'я людини, удосконалення фізичної і психічної підготовки дітей та молоді до активного довготривалого життя і професійної діяльності, забезпечує можливість набуття кожною людиною необхідних науково обгрунтованих знань про здоров’ я, засоби і методи його зміцнення, організацію дозвілля, формує спеціальні і загальні компетентності.

Компетентнісний підхід на заняттях із фізичного виховання допоможе реалізувати актуальні завдання сучасного навчання, сприяючи формуванню як загальних, так і спеціальних компетентностей студентів. На даний момент немає єдиної думки про те, скільки і яких загальних компетентностей повинно бути сформовано у випускників вищої школи, але налічується приблизно 5-15 компетентностей, які можна обирати, наприклад, з переліку проєкту Tuning Educational Structures in Europe (налаштування (гармонізація) освітянських структур в Європі; далі - TUNING) [11]. Дані компетентності визначають специфіку та включаються у профіль програми. Очікується, що програмні компетентності однакових програм у різних 3ВО подібні.

У проєкті TUNING (2012р.) ідеться про такі загальні компетентності, якими має володіти студентвипускник 3ВО: здатність до аналізу та синтезу; уміння застосовувати знання на практиці; планування та розподіл часу; базові загальні знання сфери навчання; застосування базових знань професії на практиці; усне та письмове спілкування рідною мовою; знання другої мови; елементарні навички роботи 3 персональним комп'ютером; дослідницькі вміння; здатність до самонавчання; навички роботи з інформацією (уміння знаходити й аналізувати інформацію з різних джерел); уміння самокритики та критики; здатність адаптуватися до нових ситуацій; здатність генерувати нові ідеї [11].

Загальні компетентності - універсальні компетентності, що не залежать від предметної області, але важливі для успішної подальшої професійної та соціальної діяльності здобувача в різних галузях та для його особистісного розвитку. До загальних компетентностей належать такі [5, с. 36]:

1. Інструментальні компетентності, які включають когнітивні здібності, здібності розуміти й імплантувати ідеї; методологічні здібності, екологічні здібності (розуміти й управляти навколишнім середовищем), вибудовувати стратегії навчання, задатності до ухвалення рішень і вирішення проблем, технологічні вміння, комп'ютерні навички тощо.

2. Міжособистісні компетентності, тобто індивідуальні здатності, пов'язані з умінням проявляти почуття та ставлення, здатністю до самокритики, а також соціальні навички, що пов'язані із процесами соціальної взаємодії та кооперації, умінням працювати в колективі.

3. Системні компетентності, тобто узгодження розуміння, ставлення і знань, які дозволяють розуміти, яким чином частини цілого зіставляються одна з одною, оцінити місце кожного 3 компонентів у системі, здатність планувати з метою вдосконалення системи і конструювання нових систем.

До загальних компетентностей, притаманних усім трудовим функціям за певною професією, належать соціальні, екологічні тощо, наприклад: уважність; розвинена зорова та слухова пам'ять; емоційна стійкість; стресостійкість; відповідальність; розвинена орієнтація у просторі; здатність до адаптації; здатність діяти в нестандартних ситуаціях; здатність працювати в команді; запобігання конфліктним ситуаціям [12].

В. Виноградов зазначає, що такі педагоги, як В. Давидов, В. Шадриков, І. Зимня, А. Хуторський у процесі фізичного виховання виділяють формування таких компетенцій $[13 ; 14 ; 15]$ :

- загальнокультурна (сфера культурно-історична): узагальнені види діяльності; здатність аналізувати історичний досвід; пізнання культурно-історичних основ фізичної культури, усвідомлення ролі фізичної культури у формуванні здатності до досягнення всебічного фізичного і духовного розвитку, здорового способу життя; збереження здоров'я і високої працездатності; підготовка до праці і захисту Батьківщини. Визначення впливу систематичних занять фізкультурою для поліпшення здоров'я, підвищення рівня фізичної підготовленості та профілактики захворювань; розвиток інтересу і звички до систематичних занять фізичною культурою;

- навчально-пізнавальна (сфера науки, мистецтва): здатність вчитися все життя, володіння знаннями, уміннями і навичками; пізнання основ фізичного розвитку і виховання з метою формування духовно багатої і фізично здорової особистості; здобуття знань, необхідних для занять фізичною культурою; знання основ особистої та громадської гігієни; володіння знаннями про правила регулювання фізичного навантаження;

- комунікативна (сфера спілкування): володіння усним і письмовим спілкуванням; володіння різними видами інформації; уміння вести дискусію із проблем розвитку спорту та занять фізичною культурою; виро- 
блення власної позиції із цих питань; уміння аналізувати й оцінювати діяльність друзів, однокласників; уміння давати рекомендації для самостійних занять фізкультурою, спираючись на сучасні фізкультурнооздоровчі технології;

- соціальна (сфера суспільних відносин (політика, праця, релігія, міжнаціональні відносини, екологія, здоров’я): здатність брати на себе відповідальність; брати участь у спільному ухваленні рішень; розуміння користі занять фізичними вправами для здоров’я людини, підвищення рівня ії працездатності та збільшення тривалості життя, а також ролі фізичних вправ у профілактиці професійних захворювань, у боротьбі з виробничим травматизмом; уміння використовувати засоби фізичної культури для підготовки до професійної діяльності;

- особистісна (сфера соціально-культурна): визначення основних життєвих цілей і способів їх досягнення; активна адаптація до оточення для досягнення основних життєвих цілей; володіння прийомами самореалізації; приватне і життєве самовизначення; володіння прийомами особистісного саморозвитку; уміння контролювати фізичний стан організму.

Комунікативну компетентність, як зазначає О. Пометун, можна по праву вважати провідною і стрижневою, оскільки саме вона лежить в основі всіх інших компетентностей. Комунікативну компетентність сьогодні необхідно послідовно формувати і розвивати в тісному зв'язку з навчальними й інформаційними вміннями. Навчання комунікативній діяльності є безпосереднім завданням навчання на заняттях із фізичного виховання, і починати цей процес треба якомога раніше [7].

Формування компетентностей вимагає від педагога певної програми дій, тому під час вибору форми проведення заняття варто керуватися своїми професійними й особистісними принципами, знаннями і вміннями:

1. Виховання дбайливого ставлення до власного здоров'я, набуття вмінь і навичок в індивідуальних заняттях фізичними вправами, орієнтованих на підвищення працездатності, попередження захворювань.

Засоби: комплекси ЛФК; надання першої допомоги в разі травм; профілактика шкідливих звичок засобами фізичної культури; визначення індивідуальних особливостей фізичного розвитку і підготовленості.

2. Оволодіння технологіями сучасних оздоровчих систем фізичного виховання.

Засоби: найпростіші прийоми аутогенного тренування і релаксації для зняття втоми і підвищення працездатності; дихальні вправи; авторські і східні оздоровчі методики; знання особливостей фізичної працездатності людини, чинників позитивного впливу фізичних вправ на здоров'я та формування здорового способу життя.

3. Збагачення рухового досвіду професійно-прикладними вправами, орієнтованими на підготовку до майбутньої життєдіяльності.

Засоби: загальна і професійно-прикладна фізична підготовка; володіння способами рухової діяльності; уміння виконувати тестові завдання, що визначають індивідуальний рівень фізичної підготовленості.

4. Засвоєння системи знань про заняття фізичною культурою, їхню роль і значення у формуванні здорового способу життя та соціальній орієнтації.

Знання особливостей індивідуального здоров'я, фізичного розвитку, можливостей їх корекції за допомогою занять фізичними вправами та методики їх визначення; володіння методикою організації індивідуальних форм занять фізичними вправами; уміння виконувати індивідуальні комплекси вправ, використовувати набуті знання та вміння в житті [13].

Запровадження компетентнісного підходу у фізичне виховання допоможе сформувати у студентів: здатність працювати без постійного керівництва, брати на себе відповідальність; уміння виявляти ініціативу, не питаючи інших, чи слід це робити; готовність помічати проблеми і шукати шляхи їх вирішення; уміння аналізувати нові ситуації і застосовувати в них уже наявні знання; уміння уживатися з іншими; готовність набувати нових знань із власної ініціативи (з огляду на свій досвід і зв'язок з оточенням); уміння переймати нове у спортсменів вищого класу [13].

До різних рівнів сформованості та прояву компетентностей у студентів можна віднести: 1) ступінь опанування та реалізації компетенцій у конкретному виді діяльності; 2) суб'єктивний чинник (залежність оволодіння компетенціями та їх реалізації в певному виді діяльності від притаманних конкретній особистості природних даних); 3) причинно-наслідовий зв’язок між сформованістю структурних компонентів компетентності.

Висновки. Погоджуємося 3 думкою дослідників, що компетентність зумовлює наявність в особистості внутрішньої мотивації до якісного виконання своєї професійної діяльності, професійних цінностей і ставлення до своєї професії як до цінності. Компетентний спеціаліст має бути здатним виходити за межі предмета своєї професії і володіти творчим потенціалом для саморозвитку [5, с. 34-38].

Компетентнісний підхід не заперечує значення знань, але він акцентує увагу на здатності використовувати здобуті знання в повсякденному житті і професійній сфері. Компетентнісний підхід передбачає набуття певних компетентностей, тобто необхідного комплексу знань, навичок, ставлень і досвіду, що дозволяє ефективно виконувати певну діяльність.

У подальших дослідженнях розглянемо формування загальних компетентностей на заняттях фізичного виховання відповідно до різних професій студентів ЗВО. 


\section{Використана література:}

1. Державний стандарт базової і повної загальної середньої освіти, затверджений постановою Кабінету Міністрів України від 23 листопада 2011 р. № 1392. URL: https://zakon.rada.gov.ua/laws/show/1392-2011-\%D0\%BF.

2. Про Національну стратегію розвитку освіти в Україні на період до 2021 р. : Указ Президента України від 25 червня 2013 p. № 344/2013. URL: http://zakon2.rada.gov.ua/laws/show/344/2013.

3. Сембрат А. Теоретичний аналіз компетентністного підходу в сучасному освітньому середовищі. Теоретична $i$ дидактична філологія. Серія «Педагогіка». 2017. Вип. 24. С. 175-183.

4. Проценко А. Формування професійної компетентності майбутніх учителів фізичної культури у процесі педагогічної практики : дис. ... канд. пед. наук: 13.00.04. Мелітополь, 2018. 332 с.

5. Волощук І. Формування професійної компетентності студентів ВНЗ: компетентнісний підхід. Психолого-педагогічні науки. 2014. № 3. С. 34-38.

6. Нагач М. Підготовка майбутніх учителів у школах професійного розвитку у США : автореф. дис. ... канд. пед. наук: 13.00 .04 «Теорія і методика професійної освіти». Київ, 2008. 21 с.

7. Пометун О. Компетентністний підхід - найважливіший орієнтир розвитку сучасної освіти. Рідна школа. 2005 . № 1. C. 65-69.

8. Овчарук О. Компетентності як ключ до оновлення змісту освіти. Стратегія реформування освіти в Україні : рекомендації з освітньої політики. Київ : К.І.С, 2003. 296 с.

9. Про вищу освіту : Закон України від 1 липня 2014 р. № 1556-VII, поточна редакція від 30 листопада 2016 р., підстава 1731-19. URL: http://zakon.rada.gov.ua/laws/show/1556-18.

10. Словник іншомовних слів / за ред. О. Мельничука. Київ : УРЕ, 1977. 779 с.

11. Tuning Educational Structures in Europe. URL: http://tuning.unideusto.org/tuningeu.

12. Методика розроблення професійних стандартів : наказ Міністерства соціальної політики України від 22 січня 2018 р. № 74. URL: https://zakon.rada.gov.ua/laws/show/ru/z0165-18/ed20180122/sp:java-max10\#n19.

13. Виноградов В. Розвиток ключових компетенцій учнів на уроках фізичної культури, 2014. URL: http://www.detkam.in.ua/ rozvitok-klyuchovih-kompetencij-na-urokah-fizichnoyi-kuleturi.html.

14. Методична скарбничка по фізкультурі. URL: https://infourok.ru/metodichna-skarbnichka-po-fizkulturi-723472.html.

15. Хуторской А. Ключевые компетенции и образовательные стандарты : доклад на отделении философии образования и теории педагогики. Центр «Эйдос». URL: http://www.eidos.ru/journal/2002/0423.htm.

\section{References:}

1. Derzhavnyy standart bazovoyi i povnoyi zahal'noyi seredn'oyi osvity, zatverdzhenyy postanovoyu Kabinetu Ministriv Ukrayiny vid 23.11.2011 № 1392 [State standard of basic and complete general secondary education, approved by the resolution of the Cabinet of Ministers of Ukraine № 1392 of 23.11.2011]. Retrieved fromhttps://zakon.rada.gov.ua/laws/show/1392-2011-\%D0\%BF [in Ukrainian].

2. Pro Natsional'nu stratehiyu rozvytku osvity v Ukrayini na period do 2021 roku: Ukaz Prezydenta Ukrayiny vid 25.06 .2013 r. № 344/2013 [On the National Strategy for the Development of Education in Ukraine for the Period until 2021: Decree of the President of Ukraine of 25.06.2013 № 344/2013]. Retrieved fromhttp://zakon2.rada.gov.ua/laws/show/344/2013183 [in Ukrainian].

3. Sembrat, Alla. (2017). Teoretychnyy analiz kompetentnistnoho pidkhodu v suchasnomu osvitn'omu seredovyshchi [Theoretical analysis of competence approach in modern educational environment]. Teoretychna i dydaktychna filolohiya. Seriya: "Pedahohika» - Theoretical and didactic philology. Series: Pedagogy, 24, 175-183 [in Ukrainian].

4. Protsenko, A. A. (2018). Formuvannya profesiynoyi kompetentnosti maybutnikh uchyteliv fizychnoyi kul'tury u protsesi pedahohichnoyi praktyky [Formation of professional competence of future teachers of physical culture in the process of pedagogical practice]. Candidate's thesis. Melitopol' [in Ukrainian].

5. Voloshchuk, I. P. (2014). Formuvannya profesiynoyi kompetentnosti studentiv VNZ: kompetentnisnyy pidkhid [Formation of Professional Competence of University Students: Competence Approach]. Psykholoho-pedahohichni nauky - Psychological and pedagogical sciences, 3, 34-38 [in Ukrainian].

6. Nagach, M. (2008). Pidhotovka maybutnikh uchyteliv u shkolakh profesiynoho rozvytku v SSHA [Training of future teachers in professional development schools in the USA]. Extendedabstract of candidate's thesis. Kyiv [in Ukrainian].

7. Pometun, O. (2005). Kompetentnistnyy pidkhid - nayvazhlyvishyy oriyentyr rozvytku suchasnoyi osvity [Competency approach is the most important benchmark for the development of modern education]. Ridna shkola - Home school, 1, 65-69 [in Ukrainian].

8. Ovcharuk, O. (2003). Kompetentnosti yak klyuch do onovlennya zmistu osvity. Stratehiya reformuvannya osvity $v$ Ukrayini : Rekomendatsiyi z osvitn'oyi polityky [Competencies as a key to updating the content of education. Education Reform Strategy in Ukraine: Policy Recommendations]. Kyiv: «K.I.S» [in Ukr.].

9. Zakon Ukrayiny «Pro vyshchu osvitu» vid 01.07.2014 № 1556-VII, potochna redaktsiya vid 30.11.2016, pidstava 1731-19 [The Law of Ukraine «On Higher Education» of 01.07.2014 № 1556-VII, current version as of 30.11.2016, ground 1731-19]. Retrieved fromhttp://zakon.rada.gov.ua/laws/show/1556-18[in Ukrainian].

10. Melnichuk, OS. (Eds). (1977). Slovnyk inshomovnykh sliv [Dictionary of Foreign Language Words]. Kyiv : URE [in Ukrainian].

11. Tuning Educational Structures in Europe. Retrieved fromhttp://www.unideusto.org/tuningeu/

12. Metodyka rozroblennya profesiynykh standartiv: Nakaz Ministerstva sotsial'noyi polityky Ukrayiny 22.01 .2018 № 74 [Methods of development of professional standards: Order of the Ministry of Social Policy of Ukraine 22.01.2018 № 74]. Retrieved fromhttps://zakon.rada.gov.ua/laws/show/ru/z0165-18/ed20180122/sp:java-max10\#n19 [in Ukrainian].

13. Vinogradov, V.A.(2014). Rozvytok klyuchovykh kompetentsiy uchniv na urokakh fizychnoyi kul'tury [Development of students' key competences in physical education lessons]. Retrieved from http://www.detkam.in.ua/rozvitok-klyuchovih-kompetencij-naurokah-fizichnoyi-kuleturi.html [in Ukrainian].

14. Metodychna skarbnychka po fizkul'turi [Methodical piggy bank on physical education]. (n.d.). infourok.ru. Retrieved fromhttps:// infourok.ru/metodichna-skarbnichka-po-fizkulturi-723472.html [in Ukr.].

15. Khutorskoy, A.(2002). Klyuchevyye kompetentsii i obrazovatel'nyye standarty: doklad na otdelenii filosofii obrazovaniya i teorii pedagogiki[Key competencies and educational standards: report at the department of philosophy of education and theory of pedagogy]. Tsentr «Eydos» - Center «Eidos». Retrieved from http://www.eidos.ru/journal/2002/0423.htm [in Russian]. 
Oleksiienko Ya. I., Subota V. V., Holovatenko O. M. Formation of general competence in higher education students at physical education

The article highlights the relevance of the competence approach in the higher education system. The priority of the competence approach in the organization of educational process in higher education institutions of Ukraine is substantiated. Analyzed what general competencies a graduate student should master. Some problems and peculiarities of formation of general competences in students in physical education classes are considered.

A competent approach in physical education classes will help to accomplish current tasks of the modern class, contributing to the formation of both general and special competencies of students. General competences - universal competences that are independent of the subject area, but are important for the successful further professional and social activities of the applicant in various fields and for his personal development.

A college graduate must have the following general competencies: ability to analyze and synthesize; ability to put knowledge into practice; scheduling and time allocation; basic general knowledge of the field of study; application of basic knowledge of the profession in practice; oral and written communication in the native language; knowledge of the second language; basic computer skills; research skills; self-learning ability; information skills (ability to find and analyze information from different sources); self-criticism and criticism skills; ability to adapt to new situations; the ability to generate new ideas (creativity).

Different levels of formation and display of competencies in students include: 1) the degree of mastery and implementation of competencies in a particular type of activity; 2) subjective factor (dependence of mastering of competences and their realization in a certain type of activity on inherent in a particular personality of natural data); 3) causal relationship between the formation of structural components of competence.

Key words: competence approach, competence, general competence, physical education, student, institution of higher education, employment.

\author{
УДК 378.6:355.23 (477) \\ DOI https://doi.org/10.31392/2311-5491/2019-70.45
}

Олло В. П.

\title{
ТЕОРЕТИКО-ПРАКТИЧНИЙ АНАЛІЗ РОЗВИТКУ КОНКУРЕНТОСПРОМОЖНОСТІ ОФІЦЕРІВ
}

Статтю присвячено теоретико-практичному аналізу розвитку конкурентоспроможності офічерів. Конкурентоспроможний персонал розглядають як персонал, який володіє необхідним набором компетенцій, високою самоорганізацією, внутрішньою мотивачією і начілений на виконання конкретних виробничих завдань. Ми розуміємо конкурентоспроможність офіиерів як комплексну інтегративну характеристику, що передбачає сукупність особистісно-професійних, ділових, моральних якостей і характеристик, що відображають гармонійність розвитку та забезпечують «здорову» конкуренцію. Уважаємо, тренінг є оптимальним форматом розвитку конкурентоспроможності офіцерів, завдяки якому в кожного учасника формується адекватне розуміння самого себе, корекиія самооиінки, відбувається вивчення індивідуалізованих прийомів міжособистісної взаємодії. Представлено структуру проведення тренінгового заняття, шео містить привітання; вироблення правил роботи у тренінговій групі; оголошення теми; розминку; основну частину: вступне слово тренера (міні-лекцію, інформаційні повідомлення, інструкції), різноманітні практичні вправи, ігри з подальшим обговоренням і рефлексією; підбиття підсумків роботи; прощання. Увага зосереджена на поетапній методииі застосування інтерактивних методів у процесі проведення тренінгових занять. До інтерактивних методів навчання відносимо «метод шести капелюхів», мозковий штурм, дебрифінг, ділові й ситуаційно-рольові ігри, презентаиї, групову дискусію, практичні та творчі завдання, проєктування бізнес-планів, проєктів, використання мультимедійних комп 'ютерних програм. Розкрито сутність «методу шести капелюхів», який можна використовувати під час проведення тренінгів для розвитку конкурентоспроможності офіцерів.

Ключові слова: конкурентоспроможність, розвиток, офіцери, тренінг, інтерактивні методи.

Формування особистості офіцера як суб’єкта професійної діяльності починається під час навчання у військових закладах вищої освіти. Питання професійного становлення, самовизначення й розвитку конкурентоспроможності розглядають у контексті професійного життя військовослужбовців. До професійної підготовки офіцерів висувають високі вимоги, серед яких основними $є$ професіоналізм, конкурентоспроможність, мобільність, уміння гнучко реагувати на зміни у професійній діяльності тощо.

У розумінні Н. Мартинюк, Д. Черевко [4] конкурентоспроможний персонал - це персонал, який володіє необхідним набором компетенцій, високою самоорганізацією, внутрішньою мотивацією і націлений на виконання конкретних виробничих завдань. Тому постійний розвиток офіцерів є ключовим завданням військового менеджменту, отже, потребує належного наукового супроводу.

Конкурентоспроможність офіцерів ми трактуємо як комплексну інтегративну характеристику, що передбачає сукупність особистісно-професійних, ділових, моральних якостей і характеристик, що відображають гармонійність розвитку і забезпечують «здорову» конкуренцію. Розвиток конкурентоспроможності офіцерів здійснюється в межах усебічної підготовки і становлення військових кадрів у цілісній системі діяльності військовослужбовців Збройних сил України. Досягнути цього можна через неперервну освіту офіцерів, яка водночас є метою, результатом і критерієм продуктивності системи розвитку конкурентоспроможності офі- 